Balkan and Mediterranean Candidates for European Union Membership: The Convergence of their Monetary Policy with that of the European Central Bank

$$
\text { By: Josef C. Brada and Ali M. Kutan }
$$

William Davidson Working Paper Number 456

April 2002 


\title{
BALKAN AND MEDITERRANEAN CANDIDATES FOR EUROPEAN UNION MEMBERSHIP: THE CONVERGENCE OF THEIR MONETARY POLICY WITH THAT OF THE EUROPEAN CENTRAL BANK
}

\author{
Josef C. Brada \\ Arizona State University and \\ The William Davidson Institute, University of Michigan \\ Ali M. Kutan \\ Southern Illinois University - Edwardsville and \\ Center for European Integration Studies, University of Bonn
}
Addresses:: Josef C. Brada, Department of Economics, Arizona State University Box 873806, Tempe, AZ 85287-3806, U.S.A.
Tel : (480) 965-6524 FAX : (480) 965-0748 e-mail: josef.brada@asu.edu
Ali M. Kutan, School of Business, Department of Economics and Finance
Southern Illinois University at Edwardsville
Edwardsville, IL 62026-1102, USA
Phone: (618)6503473 Fax (618)650 3047 E-mail: akutan@siue.edu

\begin{abstract}
We compare the convergence with German monetary policy of the Balkan and Mediterranean country candidates for EU membership with that of countries that have recently joined the EU. Significant linkages exist between German base money stock and that of recent members of the EU; the same holds true for some of the Mediterranean region candidates for EU membership and for Slovenia and Croatia. Among the other Balkan economies and Turkey, the ability to follow the policies of the Bundesbank is nonexistent. Such weak policy coordination suggests the need for strengthening the financial sectors of these countries, for macroeconomic stabilization and for a period in which they tie their policies more closely to the ECB before they can be considered serious candidates for EU membership.
\end{abstract}

JEL Classification Nos.: E58, F15, F36, P52

Key Words: convergence, economic integration, monetary policy, transition economies, Balkans 


\section{Introduction}

Several Mediterranean and Balkan countries are candidates for European Union (EU) enlargement in current expansion, and a number of Balkan countries and neighboring Turkey hope to be considered for membership in a future round of EU expansion. Whether these latter countries can become serious candidates for membership will depend on their ability to align themselves with the institutions and the macroeconomic policies of the EU. Although structural change and institutional adaptation to EU norms will be important in this process, the convergence of monetary policy between the EU and the candidate countries will be a necessary condition. We examine the prospects for such a convergence of monetary policies by investigating the extent to which the candidate countries have been able to achieve some measure of convergence between the evolution of their money stock with that of Germany, which we use as a historical proxy for the future monetary policy stance of the European Central Bank (ECB).

\section{EU Membership and Monetary Convergence}

Much as the Maastricht criteria played a key role in the creation of a common currency among some of the EU member countries, macroeconomic performance will play a key role in determining which of the transition economies will join the EU and when. Indeed, the introduction of the Euro among a core subset of EU countries makes macroeconomic convergence a more pressing issue than it was for earlier entrants into the EU. As McKINNON (1999, p. 132) points out, the gains to new countries from joining the EU will be realized only if "trade takes place over an exchange-rate regime that is mutually acceptable between East and West". McKINNON argues that a regime of fixed exchange rates between the candidate countries and the Euro is the regime most likely to inspire such mutual confidence and to realize the full benefits of integration. In part this is so because fixed exchange rates between the currencies of these new member countries and the Euro will facilitate the rapid growth of the new members' exports to the rest of the EU without raising fears of "beggar-thy-neighbor devaluations or unfair trading practices". Moreover, a credible adherence to a Euro peg will serve as an important spur to the structural and institutional changes required of the new members, thus guaranteeing to the EU that its new members will not backslide in their efforts at structural and institutional reform.

As WELLINK (1999, p.140) points out, "... any formal link to the euro should be preceded by policy measures which make the envisaged currency link a credible one." Among the macroeconomic indicators that most observers would view as important markers of credibility for such an exchange rate link are the inflation rate, the current account, macroeconomic policy, interest rates, productivity and employment, and indebtedness. However much observers can agree on the formal markers of stability and macroeconomic convergence, the process of transition in the Balkan candidates renders highly problematic any quantitative judgment regarding the values that these markers should take in order to make a currency peg credible.

Consider, for example, the inflation rate. The Balkan economies are undergoing considerable restructuring, and this restructuring will generate large and persistent BalassaSamuelson effects (KOPITS, 1999). Large Balassa-Samuelson effects mean that there is scope for a corresponding real appreciation of the equilibrium exchange rate. Such real appreciation would come about through rates of inflation that exceeded those in the EU. Similar reservations can be raised about the use of other traditional markers of macroeconomic performance. For example, interest rates in these countries are unlikely to reflect EU levels or cyclical fluctuations, even if these countries were to follow closely the monetary policies of the ECB. In part this is due to the large differences in risk faced by depositors and returns available to lenders in the Balkans and in the EU. 
This leaves the money stock as the most appropriate measure of convergence between the transition economy candidates for EU membership and the Euro-zone countries. In the long run, if the candidate countries are able to follow the policies of the ECB in terms of a monetary aggregate target, then, as their financial systems mature and as the transitory effects of transition on inflation and interest rates recede, they should be able to achieve the same outcomes in terms of inflation and interest rates as are achieved by the ECB. In the meantime, so long as they can mimic ECB policies regarding the growth of the money base, then any inflation differential between themselves and the $\mathrm{EU}$ can be seen as reflecting Balassa-Samuelson effects and the process of price convergence.

In the empirical work reported in this paper, we focus on base money, the narrowest monetary aggregate available. We choose this monetary aggregate over broader measures of money because base money better captures central bank policy and is less diluted by the intervention of other agents in the financial system.

The ability of these countries to follow the policy leadership of the ECB cannot be determined directly, principally because the ECB has not been in existence long enough to develop a sufficient track record of policy setting. Consequently, we use past Bundesbank policy as a proxy for the future policies of the ECB, and, if it can be demonstrated that these economies were able to follow the leadership of the Bundesbank in setting the growth of the base money stock, then we can have a high degree of confidence in the ability of these countries to follow the leadership of the ECB in setting the same aggregate.(1)

\section{Tests of Bundesbank Domination of Candidate-Country Monetary Policy}

Monthly data on base money in national currency units were obtained from line 14, "reserve money", of the IMF's IFS CD ROM. German base money, which is not available after 1998 because of the beginning of the Euro zone, was extended on the basis of Germany's share in the Euro-area base money. The base money data for Greece was not directly available, so it was constructed as the sum of the currency in circulation and the total demand deposits. We excluded data from the pre-1993 period to avoid the early transition period and its financial chaos. Our sample of countries includes five Balkan countries, Albania, Bulgaria, Croatia, Macedonia and Romania, that are not candidates for EU membership in the current round; two Mediterranean candidates expected to gain entry in the current round of EU expansion, Cyprus and Malta; Slovenia, a Balkan country also expected to gain entry in the current round, and Turkey, a country that qualifies both as Balkan and Mediterranean. We also include Austria, Finland and Sweden. The latter are the most recent members of the EU, and their inclusion will enable us to judge the degree to which these countries' policies were dominated by German monetary policy shortly before and then after their joining the EU. Finally, we include Greece, which has been an EC and then an EU member since 1981, so as to expand our coverage of the region and to see how countries that have been members for some time respond to German monetary policy. Table 1 lists the countries in our sample along with the sample period utilized for each country.

\section{A. The Long-Term Relationship between German and EU Candidates' Base Money}

The first step in our analysis is to determine the time-series characteristics of the data. As the relevant procedures are well known, we merely report that the series on base money, seasonally adjusted and in logs, for the countries examined in this paper are all $I(1)$, meaning that they must be first- differenced to make them stationary. These findings allow us to test whether each of the candidate country's base money data are cointegrated with those of Germany. If such cointegration exists, then there exists a long-term relationship between the two series, and the two series will move together over time (ENGLE and 
GRANGER, 1987), and such cointegrated variables can be represented by an errorcorrection model in which there is Granger causality (GRANGER, 1969) in at least one direction. We employed the PHILLIPS-PERRON (1988) test for cointegration. Table 1 reports the PP test statistics for cointegration between the base money series of the sample countries and Germany. It also gives the sample period for each country.

The two leading Mediterranean candidates for EU membership, Cyprus and Malta, as well as the leading Balkan candidate, Slovenia, all exhibit cointegration between their base money stocks and that of Germany. Thus we conclude that in the 1990s all three of these countries were able to coordinate their monetary policy with that of Germany. Turkey, on the other hand was not able to follow German monetary policy because we can not reject null the hypothesis that Turkish and German base money stock series are not cointegrated. Of the Balkan transition economies, only Croatia exhibits cointegration between its money

\section{Table 1 - Bivariate Cointegration Tests Phillips-Perron (PP) Test Statistics on Estimated Residuals ${ }^{1}$}

Panel A: Mediterranean and Balkan EU Candidates

\begin{tabular}{|c|c|c|c|c|c|}
\hline Country & ${ }_{\text {statistic }^{2}}^{\text {PP test }}$ & $\frac{\text { Sample }}{\text { Period }}$ & Sample Size & $\frac{\text { Degrees of }}{\text { Freedom }}$ & F-statistics \\
\hline Albania & -2.86 & $94: 12-00: 02$ & 63 & 61 & $266.7(0.00)^{*}$ \\
\hline Bulgaria & -1.68 & 93:01-98:11 & 71 & 69 & $121.9(0.00)^{*}$ \\
\hline Croatia & $-3.10^{* *}$ & 93:01-00:02 & 86 & 84 & $581.6(0.00)^{*}$ \\
\hline Cyprus & $-1.98^{* *}$ & $93: 12-00: 02$ & 75 & 73 & $35.4(0.00)^{*}$ \\
\hline Malta & $-2.08^{* *}$ & 93:01-00:01 & 85 & 83 & $7.00(0.00)^{*}$ \\
\hline Macedonia & -2.85 & 93:12-00:02 & 75 & 73 & $316.2(0.00)^{*}$ \\
\hline Romania & -1.78 & 93:09-00:02 & 78 & 76 & $276.6(0.00)^{*}$ \\
\hline Slovenia & & 93:01-00:02 & 86 & 84 & $505.3(0.00)^{*}$ \\
\hline Turkey & Austria & $93: 01-99: 11$ & 83 & 81 & $440.4(0.00)^{*}$ \\
\hline
\end{tabular}

Panel B: Recent EU Members

\begin{tabular}{|c|c|c|c|c|c|}
\hline$\underline{\text { Country }}$ & $\frac{\text { PP test }}{\text { statistic }^{2}}$ & Sample Period & Sample Size & \begin{tabular}{|l|} 
Degrees of \\
Freedom
\end{tabular} & F-statistics \\
\hline Austria & $-5.06^{*}$ & $93: 01-98: 11$ & 71 & 69 & $1199.0(0.00)^{*}$ \\
\hline Greece & $-2.81^{* \star}$ & $93: 01-00: 02$ & 86 & 84 & $1143.0(0.00)^{\star}$ \\
\hline Finland & $-3.97^{*}$ & $93: 01-98: 12$ & 72 & 70 & $129.5(0.00)^{*}$ \\
\hline Sweden & $-2.07^{* *}$ & $93: 01-00: 02$ & 86 & 84 & $12.7(0.00)^{*}$ \\
\hline
\end{tabular}

Notes:

1. The reported test statistics are based on the residuals from the following long run equation:

$$
\log X_{t}=a+b \log (\text { German monetary base })_{t}+e_{t} \text {, }
$$

where $\mathrm{X}$ represents the monetary base for an individual country under investigation and $\mathrm{e}$ is the error term . Cointegration requires that the error term be stationary. Following ENGLE and YOO's (1987)'s suggestion, up to 12 lags were initially included in unit-root tests for the error term, and the optimal lag length was chosen based on Akaike's information criterion (AIC). A lag length of three was found to be the optimal lag length in all cases, with the 
exception of Slovakia for which 6 lags were used. The F-statistic is based on the estimated long run equation above and tests the overall significance of the estimated coefficients.

2. Because the critical values are sensitive to the presence of a constant and/or trend term, cointegration tests were initially conducted using the following three models: model 1

includes a time trend and a constant term; model 2 has a constant term only; model 3 has neither time trend nor constant. The test statistics reported above and hence the significance levels are based on the best fitting model. For most countries the best model was model 3 with the critical values -2.62 and -1.95 at the 1 and $5 \%$ level, respectively. Exceptions are Albania, Croatia, and Macedonia. For these countries, model 1 was used with the critical values -3.58 and -2.93 at the 1 and $5 \%$ level, respectively.

${ }^{*}$ and ${ }^{* *}$ denote significance at the $1 \%$ and $5 \%$ level, respectively.

base series and that of Germany. None of the other Balkan transition economies exhibits cointegration with German base money.

The lack of cointegration for the transition Balkan economies, except Croatia and Slovenia, stands in stark contrast not only to the cointegration exhibited by the front-runner candidate countries, but also the three most recent EU members, Austria, Finland and Sweden, all of which exhibit cointegration with Germany. Indeed, for Austria and Finland, the PP test statistic is quite high, and that of Sweden would doubtless also be higher were we to exclude the period of financial turmoil surrounding that country's devaluation. Greece, too, exhibits significant cointegration between its base money and that of Germany despite the fact that Greece could not qualify for inclusion in the Euro zone. The implications are quite clear. Countries that belong to the EU or that are strong candidates for entry have, indeed, aligned their monetary polices to those of the Bundesbank over the past decade. Those countries that are weak candidates, with the exception of Croatia, have not succeeded in doing so. In the case of Croatia, the conclusion may be that its lack of appeal as a candidate for EU membership has more to do with its past political experience than with any shortcomings in economic policy performance, at least relative to other strong candidates for EU membership. For the other Balkan transition economies and for Turkey, the rather subtle indicator of cointegration merely echoes other more obvious shortcomings in their economic performance.

\section{B. The Short-Run Dynamics of the German - Candidate Country Base Money Relationship}

As mentioned above, if two series are cointegrated, then there exists an errorcorrection representation of the relationship between the first differences of the two series. The error correction term measures how rapidly the money base in the candidate country reacts to deviations from the long-term relationship between the two money stocks. We therefore estimated the standard VAR specification augmented by an error correction term for each of the countries for which we accepted the cointegration hypothesis. Table 2 reports the results of the regressions as specified by Equation 1:

$\Delta M_{x, t}=c_{x}+\Sigma_{i} \alpha_{x, t-i} \Delta M_{x, t-i}+\Sigma_{i} \beta_{x, t-i} \Delta M_{G e r m a n y, t-i}+y_{x} E C_{x, t-1}+\varepsilon_{x, t} \quad$ Eq. 1 where $\mathbf{M}$ is the logarithm of the stock of base money of country $\mathbf{x}$ in national units, and $\mathbf{E C}$ is the difference between that country's actual base money stock and its base money stock as predicted by the long-run relationship between the logarithm of the country's stock of base money and that of Germany. In this specification, the evolution of the growth of the national stock of base money depends on the magnitude of the coefficient of the error correction term, $\mathbf{Y}$, on the persistence of domestic monetary policy as given by $\boldsymbol{\Sigma}_{\mathbf{i}} \boldsymbol{\alpha}_{\mathbf{x}, \mathrm{t}-\mathrm{i}}$ and on the responses of the country to short term fluctuations in German monetary policy as given by $\boldsymbol{\Sigma}_{\mathbf{i}}$ $\boldsymbol{\beta}_{\mathbf{x}, \mathrm{t}-\mathrm{i}}$. We set $\mathbf{t}$ equal to 12 , meaning that changes in national and German money stocks 
were lagged for 12 months, but, in the case of Cyprus and Sweden, a likelihood ratio test indicated that a lag of only 6 months yielded satisfactory results, and we thus opted for the more parsimonious specification. For several countries, a dummy variable was used to capture a structural break caused by turbulence, change in exchange rate regime, etc. These dummy variables and the time period they cover are also reported in Table 2

The greater the value of $\mathbf{y}$, the more rapidly a country's monetary authorities react to any divergence in the long-term relationship between their base money stock and that of Germany. An examination of Table 2 reveals significant differences between the various categories of countries in our sample as well as some differences within each category. Of the four EU member countries, Austria and Finland react the most rapidly to disturbances in the long-run relationship between their money base and that of Germany. In the case of Austria, the entire gap between Austrian and German base money is eliminated within a three-month period, and, in the case of Finland, about $77 \%$ of the gap is closed. Significantly, Greece, which did not qualify for, and Sweden, which did not choose to join,

\section{Table 2: Error Correction Estimates}

Panel A: EU Candidates

\begin{tabular}{|lcccc|}
\hline \multicolumn{1}{|c}{ Variable } & Croatia & Malta & Slovenia & Cyprus \\
\hline Constant & 0.02 & -0.01 & $0.08^{* * *}$ & 0.01 \\
Ger (t-1) & 0.63 & $0.64^{* * *}$ & 0.46 & -0.05 \\
Ger (t-2) & 0.66 & $1.11^{* *}$ & -0.19 & $1.06^{* *}$ \\
Ger (t-3) & 0.01 & 0.64 & 0.37 & 0.45 \\
Ger (t-4) & 0.13 & 0.74 & -0.39 & 0.28 \\
Ger (t-5) & -0.07 & -0.37 & -1.05 & 0.18 \\
Ger (t-6) & 0.42 & 0.27 & -1.26 & 0.02 \\
Ger (t-7) & -0.23 & -1.03 & -0.91 & - \\
Ger (t-8) & 0.75 & -0.74 & -1.16 & - \\
Ger (t-9) & $1.46^{*}$ & -0.34 & -0.35 & - \\
Ger (t-10) & $1.24^{* *}$ & 1.13 & -1.81 & - \\
Ger (t-11) & 0.58 & 0.07 & 0.41 & - \\
Ger (t-12) & -0.54 & $0.85^{* * *}$ & -0.55 & - \\
Own (t-1) & $-0.26^{* *}$ & 0.17 & $-0.70^{*}$ & $-0.54^{* *}$ \\
Own (t-2) & -0.24 & -0.05 & -0.27 & -0.20 \\
Own (t-3) & -0.07 & $0.33^{* *}$ & 0.17 & $-0.18^{* *}$ \\
Own (t-4) & 0.06 & 0.14 & 0.09 & $-0.24^{* *}$ \\
Own (t-5) & $0.18^{*}$ & $0.31^{* * *}$ & 0.14 & -0.14 \\
Own (t-6) & $0.19^{*}$ & 0.10 & 0.08 & -0.02 \\
Own (t-7) & $-0.15^{*}$ & -0.01 & -0.19 & - \\
Own (t-8) & 0.04 & -0.09 & -0.21 & - \\
Own (t-9) & -0.01 & 0.15 & $0.28^{* *}$ & - \\
Own (t-10) & 0.03 & -0.13 & $0.24^{* * *}$ & - \\
Own (t-11) & -0.04 & 0.08 & 0.10 & - \\
Own (t-12) & 0.05 & 0.04 & -0.02 & - \\
Error correct. term & 0.03 & $-0.17^{*}$ & $-0.10^{* * *}$ & $-0.08^{* * *}$ \\
& & & & \\
Adj. R ${ }^{2}$ & 0.57 & 0.15 & 0.53 & 0.36 \\
F-statistics & $4.94^{*}$ & 1.47 & $4.12^{*}$ & $4.23^{*}$ \\
Sample size & 73 & 68 & 73 & 79 \\
Degrees of freedom & 47 & 46 & 47 & 65 \\
\hline
\end{tabular}


Table 2 Continued: Error Correction Estimates

Panel B: Recent EU Members

\begin{tabular}{|lcccc|}
\hline \multicolumn{1}{|c}{ Variable } & Austria & Finland & Greece & Sweden \\
\hline Constant & 0.01 & 0.01 & $0.08^{* *}$ & $-0.01^{* * *}$ \\
Ger (t-1) & $-1.13^{*}$ & $-1.15^{*}$ & -0.06 & 0.18 \\
Ger (t-2) & -0.48 & $-1.53^{* * *}$ & -0.32 & 1.03 \\
Ger (t-3) & -0.08 & -0.30 & 0.08 & -0.17 \\
Ger (t-4) & -0.07 & -0.04 & -0.28 & 0.38 \\
Ger (t-5) & -0.01 & 1.03 & 0.06 & 1.87 \\
Ger (t-6) & 0.01 & 0.66 & $-0.61^{* *}$ & 1.26 \\
Ger (t-7) & 0.43 & 0.27 & 0.39 & - \\
Ger (t-8) & -0.30 & -0.59 & $-0.76^{* *}$ & - \\
Ger (t-9) & 0.05 & $-0.92^{* * *}$ & 0.04 & - \\
Ger (t-10) & -0.43 & -0.44 & 0.13 & - \\
Ger (t-11) & -0.24 & -0.15 & 0.22 & - \\
Ger (t-12) & $-0.76^{*}$ & -0.47 & 0.41 & - \\
Own (t-1) & 0.45 & -0.10 & $0.29^{* *}$ & 0.20 \\
Own (t-2) & 0.42 & -0.18 & 0.01 & $0.22^{* *}$ \\
Own (t-3) & 0.43 & 0.06 & -0.11 & $0.13^{* * *}$ \\
Own (t-4) & $0.45^{* *}$ & $0.27^{* *}$ & 0.07 & -0.20 \\
Own (t-5) & 0.41 & $0.23^{* * *}$ & 0.02 & -0.13 \\
Own (t-6) & 0.33 & $0.30^{* * *}$ & -0.04 & $0.23^{* *}$ \\
Own (t-7) & 0.22 & 0.15 & -0.16 & - \\
Own (t-8) & 0.21 & $0.18^{* * *}$ & 0.13 & - \\
Own (t-9) & 0.07 & 0.12 & -0.19 & - \\
Own (t-10) & -0.08 & 0.08 & $0.22^{* * *}$ & - \\
Own (t-11) & -0.09 & $0.18^{* *}$ & $-0.28^{* *}$ & - \\
Own (t-12) & $0.86^{*}$ & $0.20^{* *}$ & -0.07 & - \\
Error correct. term & $-0.64^{* *}$ & $-0.31^{*}$ & $-0.15^{* * *}$ & $-0.14^{* *}$ \\
Adj. $\mathrm{R}^{2}$ & & & & \\
F-statistics & 0.81 & 0.32 & 0.22 & 0.16 \\
Sample size & $10.54^{*}$ & $2.08^{* *}$ & $1.81^{* *}$ & $2.11^{* *}$ \\
Degrees of freedom & 58 & 59 & 73 & 79 \\
\hline & 32 & 35 & 47 & 55 \\
\hline
\end{tabular}

Notes:

1. The reported significance levels are based on the NEWEY-WEST (1987) heteroskedasticity and autocorrelation consistent standard errors *, **, and ${ }^{* * *}$ denote significance levels at 1,5 , and 10 percent level, respectively. See also notes to Table 1.

2. For some countries, there was a break in the monetary base growth rates, and we used a $(0,1)$ dummy variable to capture the break. These include Slovenia (zero until 95:03 and 1 afterwards) and Cyprus (June 96=1, and zero otherwise). In addition, the Greece equation includes a structural break term for the beginning of membership in the EU. The exclusion of this term renders the error coefficient term otherwise insignificant, but the rest of the results stay qualitatively intact. 


\section{Table 3 - Short-Run Dynamics}

Chi-square test statistics for the significance of German money growth coefficients in individual money base growth equations

\section{Panel A: EU Candidate Countries Cointegrated with Germany}

\begin{tabular}{|l|cc|}
\hline \multicolumn{1}{|c|}{ Country } & Sum of coefficients & Chi-Square test stat. \\
\hline Croatia & 5.05 & $8.97(0.00)^{*}$ \\
Cyprus & 1.94 & $2.44(0.12)$ \\
Malta & 2.98 & $9.13(0.00)^{*}$ \\
Slovenia & -7.7 & $1.93(0.16)$ \\
\hline
\end{tabular}

\section{Panel B: Balkan Countries not Cointegrated with Germany}

\begin{tabular}{|l|c|c|}
\multicolumn{1}{|c|}{ Country } & Sum of coefficients & $\begin{array}{c}\text { Chi-Square test } \\
\text { stat. }\end{array}$ \\
\hline Albania & 1.46 & $0.97(0.32)$ \\
Bulgaria & 8.78 & $7.07(0.00)^{*}$ \\
Macedonia & -0.84 & $0.21(0.65)$ \\
Romania & 1.43 & $0.41(0.52)$ \\
Turkey & 3.27 & $2.68(0.10)^{* * *}$ \\
\hline
\end{tabular}

Panel C: EU Members

\begin{tabular}{|l|c|c|}
\multicolumn{1}{|c|}{ Country } & Sum of coefficients & $\begin{array}{c}\text { Chi-Square test } \\
\text { stat. }\end{array}$ \\
\hline Austria & -3.02 & $2.36(0.12)$ \\
Greece & 0.67 & $0.15(0.70)$ \\
Finland & -4.03 & $6.98(0.00)^{*}$ \\
Sweden & 4.57 & $1.69(0.19)$ \\
\hline
\end{tabular}

Notes:

1. The number of lagged German money coefficients used for Panel $A$ and $C$ countries are based on those reported in Table 2, while 12 lags are used for Panel B countries.

2. P-values are in parentheses. ${ }^{*},{ }^{* *},{ }^{* * *}$ as in Table 2.

3. In estimations, we also accounted for a structural break for Albania for 1997:01 and Turkey's 1994 financial crisis from May through November. 
the Euro zone, react more slowly than do Euro zone members Austria and Finland. Both Greece and Sweden eliminate about 38\% of the gap within three months, suggesting a looser relationship to German monetary policy.

Malta and Cyprus, the Mediterranean candidates for EU membership, adjust somewhat more slowly than the Euro-zone members, with Malta closing $46 \%$ of the gap in three months and Cyprus 23\%. Slovenia, the leading Balkan candidate for EU entry, adjusts at a rate similar to that of the Mediterranean candidates. It eliminates $28 \%$ of the gap in a three-month period. Perhaps because they are not EU members yet, these countries do not perceive the need for as close a coordination with the Bundesbank's policies as is the case for the EU, and, especially, Euro zone, member countries in our sample. Finally, the error correction term for Croatia is marginally insignificant. Indeed, as we see below, Croatia's ties to German monetary policy proceeded through another mechanism.

Thus, while both recent EU and Euro-zone member countries and the leading candidates for membership all display a measure of cointegration between their base money stocks and that of Germany, this strength of this relationship, as measured by the speed of adjustment is quite different for the two groups, with member countries, and especially Eurozone countries, responding much more quickly than do the candidate countries.

Even if candidate countries do not maintain a long-run relationship between their base money stocks and that of Germany, they may still choose to follow the policy lead of the Bundesbank by shadowing the short-term fluctuations in German money supply. To do this, they would expand their stock of base money in response to the Bundesbank's decisions to increase the growth of Germany's stock of base money, and they would slow the growth of their base money stock when the Bundesbank does so. Evidence of such short term coordination would be that the coefficients in Equation 1 that reflect the influence of lagged German money growth on the growth of a country's money stock, $\boldsymbol{\Sigma}_{\mathbf{i}} \boldsymbol{\beta}_{\mathrm{x}, \mathrm{t}-\mathrm{i}, \text { would }}$ be positive and significant.

The results of this hypothesis test are reported in Table 3 . The values of $\boldsymbol{\Sigma}_{\mathbf{i}} \boldsymbol{\beta}_{\mathrm{x}, \mathrm{t}-\mathrm{i}}$ for those countries whose money stock is cointegrated with that of Germany are drawn from Table 2; those for the other countries in our sample are drawn from a vector autoregressive (VAR) specification that is identical to Equation 1, with the exception of the error-correction term, which is absent for these countries. Table 3 reveals that Finland responds to shortterm changes in German monetary policy, although it does so in a way that offsets rather than reinforces German short-term policy decisions. Austria and Sweden do not appear to react to short-term swings in German monetary policy. This finding is not surprising, especially for Austria, given the speed with which Austria adjusts to any disturbance in the long-term relationship between its monetary policy and that of Germany. Greece also does not respond to short-run changes in German monetary policy, perhaps reflecting the fact that it did not qualify for Euro-zone membership. Malta also tracks short-term fluctuations in German monetary policy but Cyprus does not; nor does Slovenia. Croatia, for which we accepted the hypothesis of cointegration, in fact reacts to changes in German monetary policy quite strongly, as evidenced both by the high value for its $\boldsymbol{\Sigma}_{\mathbf{i}} \boldsymbol{\beta}_{\mathrm{x}, \mathrm{t}-\mathrm{i}}$ and by the high level of significance for these variables. Finally, of the countries that exhibit no long-run ties to German monetary policy, only two, Bulgaria and Turkey, respond to short-run variations in the German money base, while the rest do not.

Thus, it seems that short term tracking of German money supply is not practiced by all EU members or by all the leading candidate countries. However, the tracking of shortterm movements in German base money by Bulgaria, Croatia and by Turkey may reflect the emergence of a closer link between these countries' monetary policies and those of the $E C B$, a relationship that may at some point reverse our findings regarding the lack of cointegration between Bulgaria's and Turkey's money base series and that of Germany. Indeed, these three countries may in some sense be seen as standing ahead of Macedonia and Romania in their potential for aligning themselves with ECB policy in the future. In all, 
these short-term responses to German money stock movements do mirror those obtained from our analysis of the error correction term. The recent EU members have a stronger tie to German policy in the short run, as does Malta. The Balkan candidates are less strongly or not at all connected to German policy in the short-run, much as is the case in the long run.

\section{Conclusions}

The motivation for our inquiry was the observation that membership in the EU for both transition and market economy countries will yield mutual benefits only if a stable exchange rate regime between new members and the Euro-zone countries can be worked out that will be acceptable to both sides. Indeed, the potential for creating such a stable exchange rate relationship may be a prerequisite for candidacy in the future as the Euro zone expands it membership. A necessary, if not sufficient, condition for the long-term viability of such an exchange rate regime is that the potential new members be able to follow the lead of the ECB in setting their monetary policy. Our results show that such domination of national monetary policy by the Bundesbank, which we see as a proxy for the ECB, quite clearly characterizes the behavior of the most recent members of the EU, Austria, Finland, and Sweden as well as that of Greece. We also find a strong connection between the Bundesbank's policies and those of Cyprus and Malta, two of the market-economy Mediterranean candidates for EU membership. Among the Balkan transition economies and in Turkey, the ability to follow the policies of the Bundesbank is weaker or, for some countries, nonexistent.

An obvious implication of these findings is that those candidate countries that have as yet been unable to follow ECB policy have to set the stage for being able to do so. To achieve this objective they will have to develop their financial sectors, including the commercial banking sector, capital markets and a the ability of their central banks to act independently to set monetary policy and to exercise regulatory oversight over other agents in the financial sector. Equally important will be the fiscal policy stance of their governments. De jure independence of central banks is of little value if governments are unwilling to follow responsible fiscal policies. If these two objectives can be met, then the possibility that these economies can be stabilized successfully is quite high, and a measure of stabilization will be a prerequisite both for creating the conditions under which domestic monetary policy can begin to mimic that of the ECB and a fixed exchange rate or a crawling peg against the Euro can be made credible.

At the same time, these countries face a difficult dilemma. To the extent that they are able to conduct an independent monetary policy, one geared to their specific requirements, they should be able to achieve faster rates of economic growth and, perhaps, economic restructuring than might be possible if they follow the policies of the ECB. However, our results suggest that this advantage will come at the cost of uncertainty about the appropriate rate of exchange to set against the Euro as these countries prepare to join the EU. Even if these countries can achieve exchange rates that are near equilibrium and relatively stable against the Euro, these rates will reflect past monetary policy, and they will continue to do so even if these countries switch to being dominated by ECB policies for a few years before accession. However, once they join the EU and begin to adopt ECB policy in preparation for joining the Euro zone, their monetary policy will be different from what it was previously, and this different monetary policy will imply a different equilibrium exchange rate. Thus the challenge and the risk for the monetary authorities in these countries will be to select an exchange rate on the eve of their entry into the EU that will reflect their future monetary policies rather than their past ones.

Countries such as Slovenia that have followed German monetary policy in the 1990s may have given up a measure of monetary policy independence and suffered corresponding losses in terms of growth and the pace of restructuring. However, to the extent that their current exchange rates can be seen as being close to equilibrium, they can feel confident 
that their current exchange rate against the Euro is a relatively reliable indicator of what a sustainable parity against the Euro will be once they join the EU. While our results do not enable us to weigh the relative costs and benefits of these two approaches to monetary policy, we do note that policy makers in the countries that have joined the EU most recently as well as those in the market-economy candidate countries have opted for greater certainty about the exchange rate over monetary policy independence.

\section{ACKNOWLEDGEMENT}

* We acknowledge helpful comments from participants at a seminar presentation at the Zentrum für Europäische Integrationsforschung at the University of Bonn; at the Conference on "Reforms in Eastern Europe: From Leaving the Soviet Bloc to Entering the European Union" held at the Center for Transition Economics at Columbia University; at the Conference on "Restructuring, Stability and Development in Southeastern Europe" held at the South and East European Development Center, University of Thessaly, Volos, Greece; and at the CEPR - William Davidson Institute - University of Ljubjana "International Conference on Transition Economics", held at Portoroz, Slovenia;. We are also pleased to acknowledge the hospitality and financial support of the Zentrum für Europäischer Integrationsforschung at the University of Bonn. All shortcomings are, of course, entirely our responsibility.

\section{FOOTNOTES}

1 Thus in spirit and in methodology this study is related to the work on the Bundesbank's domination of the EMS. See, for example, von Hagen and Fratianni (1990), Karfakis and Moschos (1990), MacDonald and Taylor (1991), Kutan (1991), Kirchgässner and Wolters (1993), and Hafer, et al. (1997) for a sampling of methodologies and conclusions. 


\section{REFERENCES}

DICKEY, D. A. and FULLER, W. A., 1981, "Likelihood Ratio Statistics for Autoregressive Time Series with a Unit Root", Econometrica, 49, 1057-1072.

ENGLE, R. F. and GRANGER, C.W.J., 1987, "Co-integration and Error-Correction: Representation, Estimation and Testing", Econometrica, 55, 251-276.

ENGLE, R. F. and YOO, B., 1987, "Forecasting and Testing in Cointegrated Systems", Journal of Econometrics, 35, 143-159.

GRANGER, C. W. J., 1969, "Investigating Causal Relations by Econometric Models and Cross-Spectral Methods", Econometrica, 37, 424-438.

HAFER R.W., KUTAN, A.M. and ZHOU, S., 1997, "Linkages in EMS Term Structures: Evidence from Common Trend and Transitory Components", Journal of International Money and Finance, 16 , 595-607.

KARFAKIS, C. J., and MOSCHOS, D. M., 1990, "Interest Rate Linkages within the European Monetary System: A Time Series Analysis", Journal of Money, Credit, and Banking, 22, 388394.

KIRSCHGOSSNER, G. and WOLTERS, J., 1993, "Does the DM Dominate the Euro Market? An Empirical Investigation", Review of Economics and Statistics, 75, 773-778.

KOPITS, G., 1999, Implications of EMU for Exchange Rate Policy in Central and Eastern Europe, IMF Working Paper. Washington DC: International Monetary Fund.

KUTAN, A. M., 1991, "German Dominance in the European Monetary System: Evidence from Money Supply Growth Rates", Open Economies Review, 2, 285-294.

MATEUS, A., 1999, "Portugal's Accession to the European Union", in: Ministry of Economic Affairs of the Netherlands, ed., The Second Decade: Prospects for European Integration after Ten Years of Transition (The Hague: SDU Publishers) 153-170.

McDONALD, R.and TAYLOR, M. P., 1991, "Exchange Rates, Policy Convergence, and the European Monetary System", Review of Economics and Statistics, 73, 553-558.

McKINNON, R. I., 1999, Toward Virtual Exchange-Rate Stability in Western and Eastern Europe with the Advent of EMU, in: M. I. BLEJERr and M. SKREB, eds., Balance of Payments, Exchange Rates, and Competitiveness In Transition Economies (Boston: Kluwer) 131-158.

NEWEY, W. and WEST, K., 1987, "A Simple Positive Semi-Definite, Heteroskedasticity and Autocorrelation Consistent Covariance Matrix", Econometrica, 55, 703-708.

PHILLIPS P. P.C., and PERRON, P., 1988, "Testing for a Unit Root in Time Series Regression", Biometrica, 75, 335-346.

VON HAGEN, J. and FRATIANNI, M., 1990, "German Dominance in the EMS: Evidence from Interest Rates", Journal of International Money and Finance, 9, 358-375. 
WELLINK, A., 1999, "Joining EMU", in: Ministry of Economic Affairs of the Netherlands, ed., The Second Decade: Prospects for European Integration after Ten Years of Transition (The Hague: SDU Publishers) 135-152. 


\section{DAVIDSON INSTITUTE WORKING PAPER SERIES - Most Recent Papers}

The entire Working Paper Series may be downloaded free of charge at: www.wdi.bus.umich.edu

CURRENT AS 4/9/02

\begin{tabular}{|c|c|c|}
\hline Publication & Authors & Date \\
\hline $\begin{array}{l}\text { No. 456: Balkan and Mediterranean Candidates for European Union } \\
\text { Membership: The Convergence of their Monetary Policy with that of the } \\
\text { European Central Bank }\end{array}$ & Josef C. Brada and Ali M. Kutan & Apr. 2002 \\
\hline $\begin{array}{l}\text { No. 455: Russian Financial Transition: The Development of Institutions } \\
\text { and Markets for Growth }\end{array}$ & David M. Kemme & Oct. 2001 \\
\hline $\begin{array}{l}\text { No. 454: Does the Market Pay Off? Earnings Inequality and Returns to } \\
\text { Education in Urban China }\end{array}$ & Xiaogang Wu and $\mathrm{Yu}$ Xie & Apr. 2002 \\
\hline $\begin{array}{l}\text { No. 453: Entrepreneurs' Access to Private Equity in China: } \\
\text { The Role of Social Capital }\end{array}$ & Bat Batjargal and Mannie M. Liu & Apr. 2002 \\
\hline $\begin{array}{l}\text { No. 452: The Determinants of Privatised Enterprise Performance in } \\
\text { Russia }\end{array}$ & $\begin{array}{l}\text { Alan A. Bevan, Saul Estrin, Boris } \\
\text { Kuznetsov, Mark E. Schaffer, } \\
\text { Manuela Angelucci, Julian } \\
\text { Fennema and Giovanni } \\
\text { Mangiarotti }\end{array}$ & June 2001 \\
\hline $\begin{array}{l}\text { No. 451: Determinants of Financial Distress: What Drives Bankruptcy } \\
\text { in a Transition Economy? The Czech Republic Case }\end{array}$ & Lubomír Lízal & Jan. 2002 \\
\hline No. 450: Corporate Governance and the Global Social Void & Lee A. Tavis & Oct. 2001 \\
\hline $\begin{array}{l}\text { No. 449: Financial Architecture and Economic Performance: } \\
\text { International Evidence }\end{array}$ & Solomon Tadesse & Aug. 2001 \\
\hline $\begin{array}{l}\text { No. 448: Growth Slowdown Under Central Planning: A Model of Poor } \\
\text { Incentives }\end{array}$ & Zuzana Brixiová and Aleš Bulír & Mar. 2002 \\
\hline $\begin{array}{l}\text { No. 447: Disentangling Treatment Effects of Polish Active Labor } \\
\text { Market Policies: Evidence from Matched Samples }\end{array}$ & $\begin{array}{l}\text { Jochen Kluve, Hartmut Lehmann, } \\
\text { and Christoph M. Schmidt }\end{array}$ & Jan. 2002 \\
\hline $\begin{array}{l}\text { No. 446: The Impact of Socialist Imprinting and Search for Knowledge } \\
\text { on Resource Change: An Empirical Study of Firms in Lithuania }\end{array}$ & $\begin{array}{l}\text { Aldas Kriauciunas and Prashant } \\
\text { Kale }\end{array}$ & Mar. 2002 \\
\hline $\begin{array}{l}\text { No. 445: The Costs, Wealth Effects, and Determinants of International } \\
\text { Capital Raising: Evidence from Public Yankee Bonds }\end{array}$ & $\begin{array}{l}\text { Darius P. Miller and John J. } \\
\text { Puthenpurackal }\end{array}$ & Oct. 2001 \\
\hline No. 444: Financial Institutions, Contagious Risks, and Financial Crises & $\begin{array}{l}\text { Haizhou Huang and Chenggang } \\
\mathrm{Xu}\end{array}$ & Nov. 2001 \\
\hline No. 443: Banks as Catalysts for Industrialization & $\begin{array}{l}\text { Marco Da Rin and Thomas } \\
\text { Hellmann }\end{array}$ & Oct. 2001 \\
\hline $\begin{array}{l}\text { No. 442: Bank-Based or Market-Based Financial Systems: Which is } \\
\text { Better? }\end{array}$ & Ross Levine & Feb. 2002 \\
\hline $\begin{array}{l}\text { No. 441: Migration and Regional Adjustment and Asymmetric Shocks } \\
\text { in Transition Economies }\end{array}$ & Jan Fidrmuc & Feb. 2002 \\
\hline $\begin{array}{l}\text { No. 440: Employment and Wages in Enterprises Under Communism } \\
\text { and in Transition: Evidence From Central Europe and Russia }\end{array}$ & $\begin{array}{l}\text { Swati Basu, Saul Estrin, and Jan } \\
\text { Svejnar }\end{array}$ & June 2000 \\
\hline No. 439: Small business in Russia: A Case Study of St. Petersburg & Alessandro Kihlgren & Jan. 2002 \\
\hline $\begin{array}{l}\text { No. 438: Foreign Direct Investment as Technology Transferred: } \\
\text { Some Panel Evidence from the Transition Economies }\end{array}$ & $\begin{array}{l}\text { Nauro F. Campos and Yuko } \\
\text { Kinoshita }\end{array}$ & Jan. 2002 \\
\hline No. 437: Whistleblowing, MNC's and Peace & Terry Morehead Dworkin & Feb. 2002 \\
\hline $\begin{array}{l}\text { No. 436: A Note on Measuring the Unofficial Economy in the Former } \\
\text { Soviet Republics }\end{array}$ & $\begin{array}{l}\text { Michael Alexeev and William } \\
\text { Pyle }\end{array}$ & Sept. 2001 \\
\hline $\begin{array}{l}\text { No. 435: The Ownership School vs. the Management School of State } \\
\text { Enterprise Reform: Evidence from China }\end{array}$ & David D. Li and Changqi Wu & Jan. 2002 \\
\hline $\begin{array}{l}\text { No. 434: The Effect of Ownership and Competitive Pressure on Firm } \\
\text { Performance in Transition Countries: Micro Evidence from Bulgaria, } \\
\text { Romania and Poland. }\end{array}$ & $\begin{array}{l}\text { Manuela Angelucci, Saul Estrin, } \\
\text { Jozef Konings, and Zbigniew } \\
\text { Zolkiewski }\end{array}$ & Jan. 2002 \\
\hline No. 433: The End of Moderate Inflation in Three Transition Economies? & Josef C. Brada and Ali M. Kutan & Jan. 2002 \\
\hline
\end{tabular}

